\title{
Molecular Characterization of a Melon necrotic spot virus Strain That Overcomes the Resistance in Melon and Nonhost Plants
}

\author{
Juan A. Díaz, ${ }^{1}$ Cristina Nieto, ${ }^{2}$ Enrique Moriones, ${ }^{1}$ Verónica Truniger, $^{2}$ and Miguel A. Aranda ${ }^{2}$ \\ 'Estación Experimental "La Mayora", Consejo Superior de Investigaciones Científicas, 29750 Algarrobo-Costa, Málaga, \\ Spain; ${ }^{2}$ Centro de Edafología y Biología Aplicada del Segura (CEBAS), Consejo Superior de Investigaciones Científicas, \\ Campus Universitario de Espinardo, 30100 Espinardo, Murcia, Spain
}

Submitted 3 October 2003. Accepted 24 January 2004.

Resistance of melon (Cucumis melo L.) to Melon necrotic spot virus (MNSV) is inherited as a single recessive gene, denoted nsv. No MNSV isolates described to date (e.g., MNSV-M $\alpha 5$ ), except for the MNSV-264 strain described here, are able to overcome the resistance conferred by $n s v$. Analysis of protoplasts of susceptible ( $\mathrm{Nsv} /-$ ) and resistant (nsv/nsv) melon cultivars inoculated with MNSV-264 or MNSV-M $\alpha 5$ indicated that the resistance trait conferred by this gene is expressed at the single-cell level. The nucleotide sequence of the MNSV-264 genome has a high nucleotide identity with the sequences of other MNSV isolates, with the exception of its genomic 3 '-untranslated region (3'-UTR), where less than $50 \%$ of the nucleotides are shared between MNSV-264 and the other two MNSV isolates completely sequenced to date. Uncapped RNAs transcribed from a full-length MNSV-264 cDNA clone were infectious and caused symptoms indistinguishable from those caused by the parental viral RNA. This cDNA clone allowed generation of chimeric mutants between MNSV264 and MNSV-M $\alpha 5$ through the exchange of the last 74 nucleotides of their coat protein $(\mathrm{CP})$ open reading frames and the complete 3 '-UTRs. Analysis of protoplasts of susceptible and resistant melon cultivars inoculated with chimeric mutants clearly showed that the MNSV avirulence determinant resides in the exchanged region. The carboxytermini of the $\mathrm{CP}$ of both isolates are identical; therefore, the avirulence determinant likely consists of the RNA sequence itself. We also demonstrated that this genomic region contains the determinant for the unique ability of the isolate MNSV-264 to infect noncucurbit hosts (Nicotiana benthamiana and Gomphrena globosa).

Comparative analyses of resistance-breaking and nonresistance-breaking virus strains can help identify genetic determinants of pathogen avirulence or the mechanisms of resistance (Culver 1997). Most past reports of such efforts correspond to incompatible interactions between viruses and hosts that result in a hypersensitive response (HR) controlled by dominant resistance $(R)$ genes (Fraser 1990, 1999). The virus $R$ genes that have been cloned and sequenced to date all belong to the nucleotide binding site leucine-rich repeat (NBS-LRR) super-

Corresponding author: Miguel A. Aranda; Telephone: +34-96-8396355; Fax: +34-96-8396213; E-mail: m.aranda@cebas.csic.es

The GenBank accession number of the sequence reported in this article is AY330700. family of $R$ genes (Baker et al. 1997). Different viral proteins, including RNA-dependent RNA polymerases (Erickson et al. 1999; Hamamoto et al. 1997; Meshi et al. 1988; Padgett et al. 1997), movement proteins (Meshi et al. 1989; Weber and Pfitzner 1998; Weber et al. 1993), and coat proteins (CP) (Bendahmane et al. 1995; Berzal-Herranz et al. 1995) have been identified as avirulence determinants. In one case, an RNA sequence per se also has been described as an elicitor of an HR-like resistance response (Szittya and Burgyan 2001).

In contrast, much less information is available for incompatible interactions controlled by recessive resistance genes. Recessive mutations suppressing efficient multiplication of tobamoviruses and potyviruses have been identified and fully characterized in Arabidopsis thaliana (Duprat et al. 2002; Lellis et al. 2002; Yamanaka et al. 2000, 2002), but only two natural recessive resistance genes to potyviruses have been characterized to date (Nicaise et al. 2003; Ruffel et al. 2002). The available studies indicate that recessive genes resistant to viruses do not belong to the same classes as those controlling HR (Duprat et al. 2002; Lellis et al. 2002; Ruffel et al. 2002; Yamanaka et al. 200, 2002). For example, mutant eIF4E and eIF(iso)4E alleles (natural or generated through mutagenesis) were unable to complement accumulation of potyviruses at the single cell level (Duprat et al. 2002; Lellis et al. 2002; Ruffel et al. 2002) and several lines of evidence indicate that this recessive resistance could be due to incompatibility between the Potyvirus genome-linked protein (VPg) and eIF4E/eIF(iso)4E (Leonard et al. 2000; Ruffel et al. 2002; Schaad et al. 2000; Wittman et al. 1997).

Melon necrotic spot virus (MNSV; family Tombusviridae, genus Carmovirus) (Hibi and Furuki 1985) is an isometric monopartite plant virus endemic in cucurbit crops worldwide. In nature, MNSV is transmitted by the fungus Olpidium bornovanus and through the seed. MNSV host range is limited almost exclusively to species of the family Cucurbitaceae, in which the symptoms are necrotic spots or large necrotic lesions of the leaves, and necrosis of the stems (Hibi and Furuki 1985; Matsuo et al. 1991). MNSV has a single-stranded and positivesense RNA genome of $4.3 \mathrm{~kb}$ which contains at least five open reading frames (ORFs). The ORF at the $5^{\prime}$ end terminates in an amber codon so that the translation of this ORF would yield a $29-\mathrm{kDa}$ protein and an $89-\mathrm{kDa}$ read-through product. Two small, centrally located ORFs each encode a $7-\mathrm{kDa}$ protein. The first of these two ORFs terminates in an amber codon whose read-through could result in the production of a $14-\mathrm{kDa}$ fusion protein. The $3^{\prime}$ proximal ORF encodes the $42-\mathrm{kDa} \mathrm{CP}$ (Díaz et al. 2003; Riviere and Rochon 1990). The homologue 
28/89-kDa and the 7-kDa proteins of Turnip crinkle virus (TCV), a better-studied member of the genus Carmovirus $(\mathrm{Qu}$ and Morris 1999), have been assigned functions of replication and movement, respectively.

Control of MNSV-induced diseases in melon crops has been achieved through the use of certified seed, control of its fungal vector, and, most significantly, incorporating the $n s v$ recessive resistance gene (Coudriet et al. 1981) into commercial melon (Cucumis melo L.) hybrids. However, recently we have identified an MNSV isolate (MNSV-264) able to overcome the resistance conferred by $n s v$ (Díaz et al. 2002). To our knowledge, MNSV-264 is the only MNSV isolate described to date able to overcome this resistance. The purpose of the present study was to characterize the melon-MNSV interaction controlled by the $n s v$ resistance gene. We have determined the complete nucleotide sequence of the MNSV-264 genomic RNA, produced an MNSV-264 cDNA infectious clone, analyzed the step in which the viral infection cycle is blocked in melons of the $n s v / n s v$ genotype, and studied the ability of MNSV chimeric mutants to infect resistant and susceptible melon plants. Also, we showed that MNSV-264, unlike any other known MNSV isolates, is able to infect noncucurbit species, and we mapped the genetic determinant for this property to the same genomic region implicated as an avirulence determinant for the $n s v$ resistance.

\section{RESULTS}

\section{MNSV-264 overcomes the resistance conferred}

by the nsv gene.

Purified MNSV-264 (Díaz et al. 2002) was inoculated onto expanded cotyledons of the melon cvs. Planters Jumbo, Primal F1, and PI161345 (nsv/nsv genotype, resistant) and PMR-45 (Nsv/- genotype, susceptible). Symptoms were recorded and samples were taken from different tissues of inoculated plants at 3, 6, and 21 days post inoculation (dpi). MNSV-Dutch (Riviere and Rochon 1990) and MNSV-Ma5 (Díaz et al. 2003) also were included in this experiment as reference isolates. Results of this experiment showed that, although MNSV264 was able to induce the appearance of characteristic necrotic lesions in inoculated cotyledons and systemic tissues of all four melon cultivars, MNSV-Dutch and MNSV-M $\alpha 5$ were able to induce the appearance of symptoms only in tissues of plants of the susceptible PMR-45 cultivar. Correspondingly,

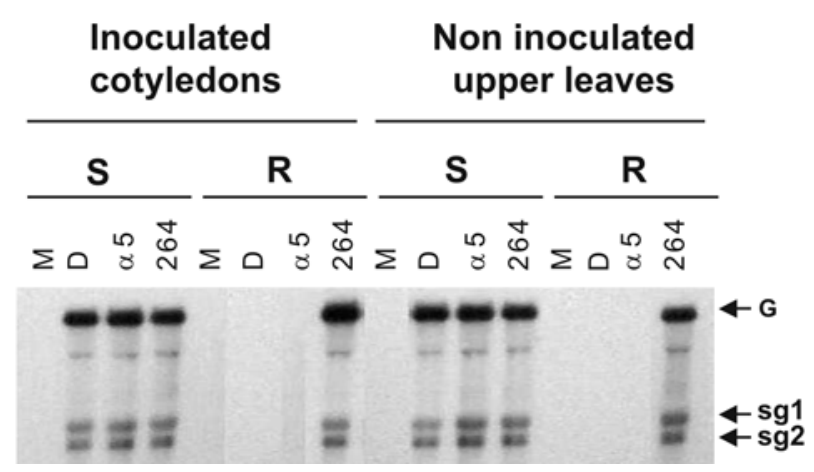

Fig. 1. Northern blot analysis of total RNA extracts of melon plants inoculated with Melon necrotic spot virus (MNSV). Cotyledons of melon plants of the $N s v /-$ genotype (susceptible, S) and of the $n s v / n s v$ genotype (resistant, R) were inoculated with MNSV-Dutch (D), MNSV-M $\alpha 5(\alpha 5)$, and MNSV-264 (264) or mock-inoculated (M). Total RNA extracts were prepared from inoculated cotyledons at 6 days post inoculation (dpi) and from upper, noninoculated leaves at 21 dpi. Total RNA ( $2 \mu \mathrm{g})$ was loaded on each lane; the amount and integrity of RNA was checked previously by ethidium bromide staining of agarose gels. The positions of genomic (G) and subgenomic (sg1 and 2) MNSV RNAs are indicated. The cRNA probe used was synthesized from a full-length MNSV-M $\alpha 5$ cDNA clone.
MNSV-264 RNAs were detected by Northern blot hybridization of total RNA extracts from tissues of plants of all four melon cultivars, whereas MNSV-Dutch or MNSV-M $\alpha 5$ RNAs were detected only in tissues of plants of the susceptible PMR45 cultivar (Fig. 1). These results confirmed that MNSV-264 can overcome the resistance conferred by the $n s v$ gene. Neither MNSV-Dutch nor MNSV-M $\alpha 5$ RNAs were detected in inoculated cotyledons of plants of the resistant cultivars (Fig. 1), suggesting that this resistance is expressed either at a single-cell level or very early after inoculation during the formation of the initial infection foci.

\section{A full-length MNSV-264 cDNA clone can be transcribed into infectious RNA.}

Nucleotide sequences corresponding to the $5^{\prime}$ and $3^{\prime}$ ends of the MNSV-264 RNA were determined by sequencing cDNA clones produced by reverse transcription-polymerase chain reaction (RT-PCR) on 3'-adenylated viral dsRNA and genomic RNA, respectively. Using this sequence information, fulllength cDNA was obtained by RT-PCR on viral RNA. This full-length cDNA was cloned (clone pTOPO-264; discussed below) and completely sequenced. This sequence, combined with the $5^{\prime}$ - and $3^{\prime}$-end sequences previously obtained, defined the complete genome sequence of MNSV-264, which consisted of 4,310 nucleotides (nt). An analysis of the nucleotide sequence coding capacity revealed that the MNSV-264 genome contains five ORFs (Fig. 2). Preceding the first ORF is a $5^{\prime}$-untranslated region $\left(5^{\prime}\right.$-UTR) of $87 \mathrm{nt}$. The 5'-proximal ORF (nucleotides 88 to 894 ) encodes a $29-\mathrm{kDa}$ polypeptide (p29). This reading frame terminates in an amber codon, but remains open until nucleotide 2,463 . Thus, if read-through occurs, a protein of $89 \mathrm{kDa}(\mathrm{p} 89)$ would be produced. Another ORF (nucleotides 2,442 to 2,639) coding for a 7-kDa protein (p7A) overlaps with the p89 ORF and terminates in an amber codon. The next ORF (nucleotides 2,643 to 2,828) is in the same frame as p7A ORF and codes for a similarly small 7-kDa protein $(\mathrm{p} 7 \mathrm{~B})$. A protein of $14 \mathrm{kDa}(\mathrm{p} 14)$ would be produced if read-through of the second amber codon occurred. The $3^{\prime}-$ proximal ORF (nucleotides 2,815 to 3,987 ) overlaps with p7B ORF and codes for the CP (42 kDa). The stop codon of the CP ORF is followed by a $3^{\prime}$-UTR of $323 \mathrm{nt}$. Therefore, the genome organization of MNSV-264 appears to be similar to that of the other MNSV isolates, including MNSV-Dutch (Riviere and Rochon 1990) and MNSV-M $\alpha 5$ (Díaz et al. 2003).

Viral RNA was obtained from the clone pTOPO-264 by in vitro transcription. The infectivity of transcribed RNA was analyzed by inoculating it into cv. PMR-45 (susceptible) and cv. Planters Jumbo (resistant) melon seedlings, as well as cu-

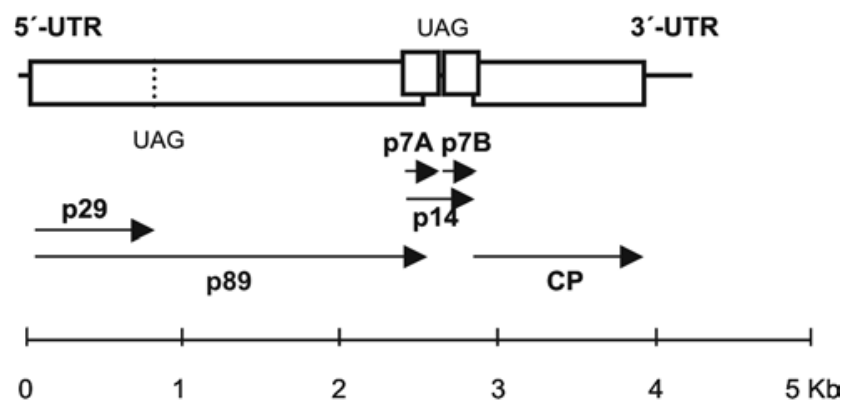

Fig. 2. Genomic organization and probable translation strategy of Melon necrotic spot virus (MNSV)-264. The genomic RNA is represented by a line. Open reading frames are shown as boxes in the middle or below the line depending on the frame they are in. Arrows represent putative translation products (p29, p89, p7A, p7B, p14 and coat protein [CP]). The termination codons proposed to be read-through (UAG) and the $5^{\prime}$ and $3^{\prime}$-untranslated regions (UTRs) are indicated. 
cumber (Cucumis sativus) cv. Bell Puig and watermelon (Citrullus lanatus) cv. Sugar Baby seedlings (discussed below). Inoculations with equivalent amounts of viral RNA extracted from virions were performed as control in these tests. Similar amounts of viral RNA per lesion $(283.7 \pm 15.7$ and $269.0 \pm 12.8 \mathrm{ng}$, respectively) and of virus per lesion (optical density at $405 \mathrm{~nm}=0.632 \pm 0.032$ and $0.614 \pm 0.036$, respectively) were detected following inoculation with the two preparations. In addition to that, the lesions developed at the same rate and had similar appearance. Finally, whenever the infection became systemic, similar symptoms were observed in the young new leaves of plants inoculated with either viral RNA or in vitro transcribed RNA. Therefore, we concluded that the

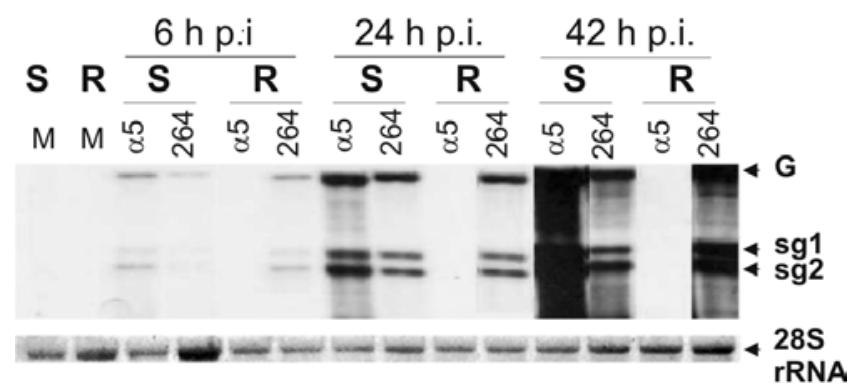

Fig. 3. Northern blot analysis of total RNA extracts of melon protoplasts inoculated with Melon necrotic spot virus (MNSV). Protoplasts of melons of the Nsv/- genotype (susceptible, S) and of the nsv/nsv genotype (resistant, R) were electroporated with MNSV-M $\alpha 5$ RNA ( $\alpha 5)$ or MNSV264 RNA (264) or mock-inoculated (M). Samples of MNSV-inoculated protoplast were taken at 6,24 , and $42 \mathrm{~h}$ post inoculation (hpi). Samples of mock-inoculated protoplasts were taken only at 42 hpi. Total RNA extracts corresponding to $2 \times 10^{5}$ protoplasts were loaded on each lane. The amount of total RNAs loaded was visualized by methylene blue staining of the 28S rRNA (bottom panel). The positions of genomic $(\mathrm{G})$ and subgenomic ( $\operatorname{sg} 1$ and 2) MNSV RNAs are indicated on the right of the top panel. The cRNA probe used was synthesized from a full-length MNSV-M $\alpha 5$ cDNA clone.

Table 1. Percentage of amino acid identity (above diagonal) and similarity (below diagonal) between proteins coded by genomes ${ }^{\mathrm{a}}$

\begin{tabular}{|c|c|c|c|c|c|}
\hline $\begin{array}{l}\text { Protein, } \\
\text { MNSV isolate }\end{array}$ & 264 & $M \alpha 5$ & Dutch & NK & NH \\
\hline \multicolumn{6}{|l|}{ p89 } \\
\hline 264 & 100 & 95 & 99 & 97 & 97 \\
\hline$M \alpha 5$ & 98 & 100 & 96 & 95 & 95 \\
\hline Dutch & 99 & 99 & 100 & 97 & 97 \\
\hline NK & 99 & 98 & 99 & 100 & 98 \\
\hline NH & 99 & 98 & 99 & 99 & 100 \\
\hline \multicolumn{6}{|l|}{ p7A } \\
\hline 264 & 100 & 92 & 96 & 96 & 98 \\
\hline$M \alpha 5$ & 93 & 100 & 92 & 92 & 94 \\
\hline Dutch & 96 & 93 & 100 & 97 & 98 \\
\hline NK & 96 & 93 & 97 & 100 & 98 \\
\hline $\mathrm{NH}$ & 98 & 95 & 98 & 98 & 100 \\
\hline \multicolumn{6}{|l|}{ p7B } \\
\hline 264 & 100 & 91 & 98 & 98 & 98 \\
\hline$M \alpha 5$ & 95 & 100 & 90 & 93 & 93 \\
\hline Dutch & 100 & 95 & 100 & 97 & 96 \\
\hline NK & 98 & 96 & 98 & 100 & 100 \\
\hline NH & 98 & 96 & 98 & 100 & 100 \\
\hline \multicolumn{6}{|l|}{$\mathrm{p} 42(\mathrm{CP})$} \\
\hline 264 & 100 & 95 & 95 & 97 & 96 \\
\hline$M \alpha 5$ & 97 & 100 & 95 & 96 & 96 \\
\hline Dutch & 98 & 98 & 100 & 97 & 96 \\
\hline NK & 98 & 98 & 99 & 100 & 99 \\
\hline $\mathrm{NH}$ & 98 & 98 & 98 & 99 & 100 \\
\hline
\end{tabular}

${ }^{\mathrm{a}}$ Genomes of Melon necrotic spot virus (MNSV)-264 (264), MNSV-M $\alpha 5$ (M $\alpha 5)$ (Díaz et al. 2003), MNSV-Dutch (Dutch) (Riviere and Rochon 1990), MNSV-NK (NK), and MNSV-NH (NH) (Ohshima et al. 2000).
cDNA insert cloned in pTOPO-264 represents a biologically active DNA copy of MNSV-264.

Resistance conferred by $n s v$ acts at the single-cell level.

The accumulation of MNSV RNAs was studied in melon protoplasts of susceptible and resistant genotypes in a timecourse experiment. Protoplasts of the PMR-45 (susceptible) and Planters Jumbo (resistant) cultivars were electroporated with transcript RNAs corresponding to MNSV-M $\alpha 5$ (not able to overcome the resistance conferred by the $n s v$ gene) (Díaz et al. 2003) or with transcript RNAs corresponding to MNSV264. Northern blot analysis of total RNAs extracted from protoplasts at 6, 24, and $42 \mathrm{~h}$ post inoculation (hpi) showed that MNSV RNAs accumulate in protoplasts of the susceptible cultivar independently of the isolate used for electroporations (Fig. 3). However, accumulation of MNSV RNAs in protoplasts of the resistant cultivar occurred only when MNSV-264 was used for electroporations (Fig. 3). No hybridization signal was detected in Northern blots of total RNA extracted from protoplasts of the resistant cultivar inoculated with transcript RNAs from MNSV-M $\alpha 5$ even at 42 hpi (Fig. 3) and after overexposure of blots (data not shown).

\section{The genetic determinant of MNSV avirulence on $n s v / n s v$ melon genotypes maps at the $3^{\prime}$ portion of the MNSV genome.}

The amino acid and nucleotide sequences of MNSV-264, MNSV-M $\alpha 5$, MNSV-Dutch, MNSV-NK, and MNSV-NH (Díaz et al. 2003; Ohshima et al. 2000; Riviere and Rochon 1990) were compared (Table 1; Fig. 4). Amino acid identity percentages ranged from 90 to $100 \%$ for $\mathrm{p} 7 \mathrm{~B}$ (lowest homology of all viral proteins) to 95 to $99 \%$ for CP (highest homology of all viral proteins) (Table 1). Thus, MNSV-264 putative proteins seem to be very similar to those of MNSV-M $\alpha 5$, MNSV-Dutch, MNSV-NK, and MNSV-NH. At the nucleotide sequence level, the percentages of identity for whole genomes ranged between 84 and $98 \%$, with MNSV-M $\alpha 5$ appearing more distantly related to the other isolates based on sequence variability. Interestingly,

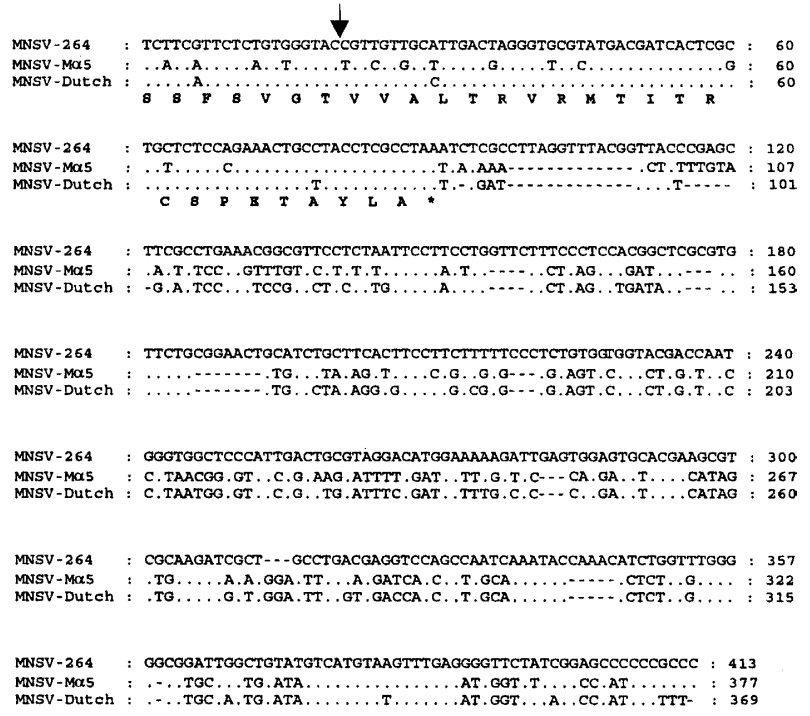

Fig. 4. Comparison of the last 400 nucleotides of the genomic sequence of isolate Melon necrotic spot virus (MNSV)-264 with those of isolates MNSV-M $\alpha 5$ and MNSV-Dutch. Nucleotides differing in the sequences of MNSV-M $\alpha 5$ and MNSV-Dutch are indicated. Dots represent identical nucleotides. Dashes indicate absence of nucleotides. Translation of the nucleotide sequence of the coat protein open reading frame into amino acids appears in bold type. An arrow indicates the position from which cDNA fragments corresponding to MNSV-M $\alpha 5$ and MNSV-264 were exchanged to produce chimeric mutants. 
nucleotide identity of MNSV-264 with other isolates was high, except in its $3^{\prime}$-end genomic region. An alignment of the last $400 \mathrm{nt}$ of isolates MNSV-264, MNSV-M $\alpha 5$, and MNSV-Dutch (Fig. 4) showed that MNSV-264 has a high nucleotide similarity with nonresistance-breaking isolates up to position 3,987 of its genomic RNA. This position corresponds to the last nucleotide of the CP ORF. However, from position 3,987 on, nucleotide similarity values decreased drastically; less than $50 \%$ of the nucleotides are shared between MNSV-264 and the other two MNSV isolates (Fig. 4). Notably, a database search did not identify any sequence with significant similarity to the MNSV264 3'-UTR.

We further postulated that this dissimilar 3'-end genomic region could be an avirulence determinant for the $n s v$ resistance. To test this, two chimeric virus mutants were constructed and their phenotypes characterized. The DNA constructs pTOPO$264 / 3^{\prime} \mathrm{M} \alpha 5$ and pTOPO-M $\alpha 5 / 3^{\prime} 264$ were prepared by exchanging the last $74 \mathrm{nt}$ of the CP ORFs plus the $3^{\prime}$-UTRs between MNSV-M $\alpha 5$ and MNSV-264 cDNA clones. Importantly, the carboxy-terminal amino acids of the MNSV-264 and MNSVM 5 CP are identical (Fig. 4). Transcript RNAs obtained from these chimeric constructs and from clones representing the fulllength genomes of MNSV-M $\alpha 5$ and MNSV-264 were electroporated into protoplasts of PMR-45 (susceptible) and Planters Jumbo (resistant) melon cultivars. Northern blot analysis of total RNAs extracted from these protoplasts at 30 hpi showed that MNSV RNAs accumulated in protoplasts of the susceptible cultivar independently of the origin of the transcript RNA used for electroporation (Fig. 5). In contrast, in protoplasts of the resistant cultivar, MNSV RNAs accumulated only when the $3^{\prime}$ portion of the viral genome corresponded to that of MNSV-264; when this region was that of MNSV-M $\alpha 5$, no viral RNAs could be detected (Fig. 5). Therefore, the genetic determinant for the MNSV avirulence on $n s v / n s v$ melon genotypes resides in the genomic region exchanged to produce the chimeric mutant viruses.

\section{MNSV-264 infects noncucurbit plant species and the genetic determinant of this property also maps at the $3^{\prime}$ portion of the viral genome.}

Host ranges of MNSV-264, MNSV-M $\alpha 5$, and MNSV-Dutch were studied by their mechanical inoculation into a collection of plant species followed by evaluation of symptoms and virus accumulation (Table 2). Although all three MNSV isolates in-

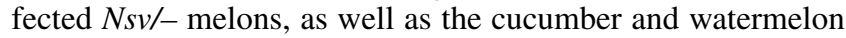
cultivars used, none of them infected any of the two Cucurbita maxima $\times$ Cucurbita moschata interspecific hybrids tested. Interestingly, MNSV-264 induced symptoms and accumulated in inoculated leaves of Gomphrena globosa and also systemically infected Nicotiana benthamiana plants, in contrast to MNSVDutch and MNSV-M $\alpha 5$, which neither induced symptoms nor accumulated in plants of these species (Table 2). Therefore, MNSV-264 appeared to have a broader host range than other MNSV isolates.

Furthermore, we wanted to map the genetic determinant for the ability of isolate MNSV-264 to infect $N$. benthamiana and G. globosa plants To achieve this, plants of these species were inoculated with RNAs that were either transcribed from DNA constructs pTOPO-264/3'M $\alpha 5$ and pTOPO-M $\alpha 5 / 3^{\prime} 264$ or from full-length clones of their corresponding parental viruses. Results of this experiment showed that plants inoculated with viruses containing the $3^{\prime}$ portion of the MNSV-264 genome developed symptoms in inoculated leaves at 4 to 5 dpi and systemic symptoms appeared in $N$. benthamiana plants at 10 to 12 dpi (Fig. 6). Correspondingly, MNSV RNAs could be detected in symptomatic tissues of these plants (data not shown). However, none of the plants inoculated with viruses containing the $3^{\prime}$ portion of the MNSV-M $\alpha 5$ genome either developed symptoms (Fig. 6) or accumulated detectable quantities of MNSV RNA in their tissues (data not shown).

\section{DISCUSSION}

Little information is available about mechanisms underlying plant resistance to viruses controlled in the host by recessive genes (Harrison 2002; Johansen et al. 2001; Ruffel et al. 2002).

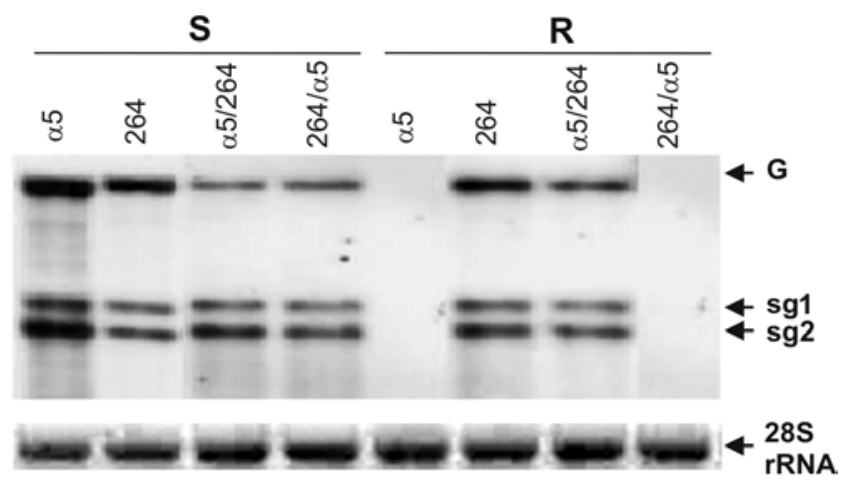

Fig. 5. Northern blot analysis of total RNA extracts of melon protoplasts inoculated with Melon necrotic spot virus (MNSV) chimeric mutants. Protoplasts of melons of the Nsv/- genotype (susceptible, S) and of the $n s v / n s v$ genotype (resistant, R) were electroporated with MNSV-M $\alpha 5$ $(\alpha 5)$, MNSV-264 (264), MNSV-M $\alpha 5 / 3^{\prime} 264$ ( $\left.\alpha 5 / 264\right)$, and MNSV$264 / 3^{\prime} M \alpha 5(264 / \alpha 5)$ transcript RNAs. Samples of inoculated protoplast were taken at $30 \mathrm{~h}$ post inoculation. Total RNA extracts corresponding to $2 \times 10^{5}$ protoplasts were loaded on each lane. The amount of total RNAs loaded was visualized by methylene blue staining of the $28 \mathrm{~S}$ rRNA (bottom panel). The positions of genomic (G) and subgenomic (sg1 and 2) MNSV RNAs are indicated on the right of the top panel. The cRNA probe used was synthesized from a full-length MNSV-M $\alpha 5$ cDNA clone.

Table 2. Host ranges of Melon necrotic spot virus (MNSV)-264, MNSV-M $\alpha 5$ (Díaz et al. 2003), and MNSV-Dutch (Riviere and Rochon 1990) ${ }^{\text {a }}$

\begin{tabular}{|c|c|c|c|c|c|c|c|}
\hline \multirow[b]{2}{*}{ Family } & \multirow[b]{2}{*}{ Species (resistance genotype) } & \multicolumn{2}{|c|}{ MNSV-264 } & \multicolumn{2}{|c|}{ MNSV-M $\alpha 5$} & \multicolumn{2}{|c|}{ MNSV-Dutch } \\
\hline & & IC & NIL & IC & NIL & IC & NIL \\
\hline \multirow[t]{6}{*}{ Cucurbitaceae } & Cucumis melo cv. PMR 45 (Nsv/-) & $\mathrm{NL} /+$ & $\mathrm{SN} /+$ & $\mathrm{NL} /+$ & $\mathrm{SN} /+$ & $\mathrm{NL} /+$ & $\mathrm{SN} /+$ \\
\hline & Citrullus lanatus cv. Sugar Baby & $\mathrm{NL} /+$ & $\mathrm{SN} /+$ & $\mathrm{NL} /+$ & $\mathrm{SN} /+$ & $\mathrm{NL} /+$ & $\mathrm{SN} /+$ \\
\hline & Cucumis sativus cv. Bellpuig & $\mathrm{NL} /+$ & $\mathrm{SN} /+$ & $\mathrm{NL} /+$ & $\mathrm{SN} /+$ & $\mathrm{NL} /+$ & $\mathrm{SN} /+$ \\
\hline & (Cucurbita maxima $\times$ C. moschata) $\mathrm{cv}$. Brava & $-1-$ & $-1-$ & $-1-$ & $-1-$ & $-1-$ & $-1-$ \\
\hline & C. ficifolia & $-1-$ & $-1-$ & $-1-$ & $-1-$ & $-1-$ & $-1-$ \\
\hline & (C. maxima $\times$ C. moschata) cv. RS841 & $-1-$ & $-1-$ & $-1-$ & $-1-$ & $-1-$ & $-1-$ \\
\hline Solanaceae & Nicotiana benthamiana & $\mathrm{NL} /+$ & $\mathrm{SN} /+$ & $-1-$ & $-1-$ & $-1-$ & $-1-$ \\
\hline Amarantaceae & Gomphrena globosa & $\mathrm{NL} /+$ & $-1-$ & $-1-$ & $-1-$ & $-1-$ & $-1-$ \\
\hline
\end{tabular}

a Inoculated cotyledons or leaves (IC) were analyzed at 3 and 6 days post inoculation (dpi) for visual symptom development and presence of virus particles. NL, necrotic lesions; -/, no symptoms; /-, negative in enzyme-linked immunosorbent assay (ELISA) tests; /+, positive in ELISA tests. Upper, noninoculated leaves (NIL) were analyzed at 6 and 21 dpi for visual symptom development and presence of virus particles. SN, systemic necrotic symptoms. 
The identification of the resistance-breaking strain MNSV-264 (Díaz et al. 2002) provided us the opportunity to study the melon-MNSV interaction controlled by the recessive $n s v$ gene. During these studies, we demonstrated that this resistance is expressed at the single-cell level and that the genetic determinant for overcoming the resistance maps at the $3^{\prime}$ portion of the MNSV-264 genome. Furthermore, we showed that this same genomic portion is involved in the ability of MNSV-264 to infect noncucurbit host species. These findings make the melon-MNSV experimental system potentially interesting to study the requirements for virus accumulation in host cells.

\section{Mapping MNSV avirulence determinants.}

Comparisons of the amino acid sequences of the putative MNSV-264 proteins with those of other MNSV isolates showed that they are very similar. In contrast, nucleotide sequence comparisons revealed striking differences as the sequence of MNSV-264, which differed markedly from any other MNSV isolate in the region comprising the $3^{\prime}$ portion of its genomic RNA (i.e., the complete $3^{\prime}$-UTR). The difference is so pronounced (nucleotide identity decreases below $50 \%$ in this region) that we speculated that this genomic region may have been acquired through RNA recombination between MNSV and non-MNSV RNA molecules. However, to date, we
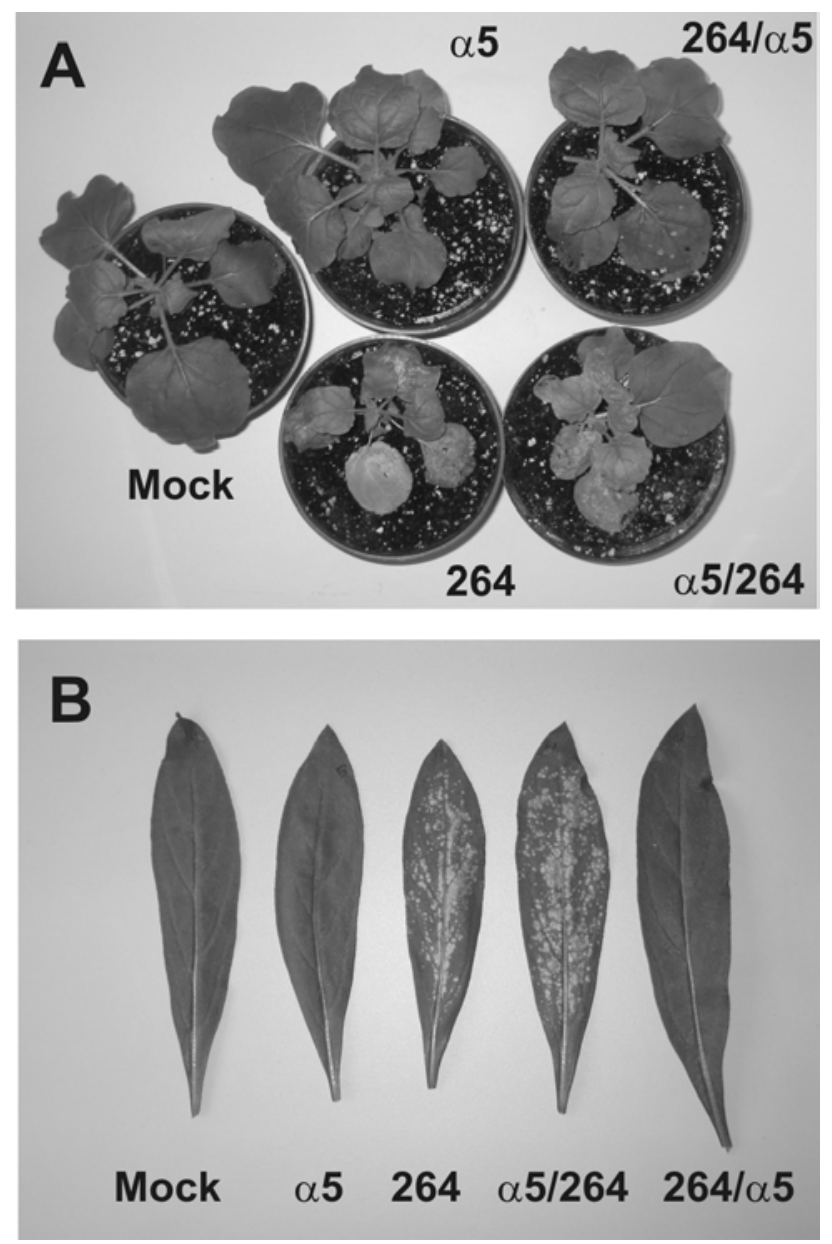

Fig. 6. A, Nicotiana benthamiana and B, Gomphrena globosa plants inoculated with Melon necrotic spot virus (MNSV) chimeric mutants. Young but fully expanded leaves of $N$. benthamiana seedlings and G. globosa plants were mock inoculated (mock) or inoculated with MNSV-M $\alpha 5$

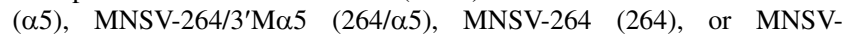
M $\alpha 5 / 3^{\prime} 264(\alpha 5 / 264)$ transcript RNAs. Plants were maintained in growth chambers and photographed $\mathbf{A}, 2$ weeks after inoculation ( $N$. benthamiana) or B, 5 days after inoculation ( $G$. globosa). have been unable to identify the possible origin of this MNSV264 genomic region because all our database searches looking for sequences with significant similarity to the MNSV-264 3'UTR were unsuccessful.

Our results suggest that the MNSV avirulence determinant could reside in the MNSV-264 3'-UTR. Characterization of chimeric mutants generated between MNSV-264 and MNSV-M $\alpha 5$ showed clearly that the ability to overcome the resistance conferred by the $n s v$ gene resides in the $397 \mathrm{nt}$ at the $3^{\prime}$ end of the MNSV-264 RNA. This region comprises the last $74 \mathrm{nt}$ of the CP ORF and the entire 3'-UTR. The carboxy-terminal amino acids of the MNSV-264 and MNSV-M $\alpha 5$ CP are identical; therefore, the MNSV avirulence determinant likely consists of the RNA sequence itself. The implication of the MNSV 3'-UTR as avirulence determinant is especially plausible because this region is predicted to fold into significantly different secondary structures for MNSV-264 and MNSV-Ma5 (C. Nieto, J. A., Díaz, V. Truniger and M. A. Aranda, unpublished results). Additionally, we have demonstrated that the ability of MNSV-264 to infect $N$. benthamiana (locally and systemically) and G. globosa (locally) plants also maps at the same $3^{\prime}$ portion of the viral genome. Therefore, the nonhost ( $N$. benthamiana and G. globosa) and cultivar (melon) resistances seem to depend on the same viral genetic determinant.

We are aware of only one other case where an RNA sequence per se has been demonstrated to be an avirulence determinant. An 860-nt long RNA sequence in the Cymbidium ringspot virus (CymRSV) CP coding region was shown to be an elicitor of an HR-like response in Datura stramonium, which limits the spread of CymRSV (Szittya and Burgyan 2001). The main differences between the CymRSV-D. stramonium system and the MNSV-melon system described in this study are in the type of host response (HR versus immunity) and that the genetic control of the response of D. stramonium is not known (Szittya and Burgyan 2001). Therefore, parallels between the two cases are rather difficult to establish.

\section{Mode of action of $n s v$.}

The recessive $n s v$ resistance gene was identified long ago (Coudriet et al. 1981) and hybrid melon cultivars carrying such resistance are used widely in commercial agriculture (J. A. Díaz and M. A. Aranda, unpublished observations). However, little was known about the $n s v$ mode of action. Detailed analysis with melon protoplasts from susceptible and resistant cultivars inoculated with MNSV-264 and MNSV-M $\alpha 5$ showed clearly that this resistance is expressed at the single-cell level. This type of response is similar to other host responses to virus inoculation classified as immunity (Johansen et al. 2001; Keller et al. 1998; Murphy et al. 1998).

Recessive resistance might be due to the lack of a specific host factor required by the virus or due to the presence of a mutated version of that factor (Fraser 1999). All virus recessive resistances characterized to date agree with this model (Johansen et al. 2001; Keller et al. 1998; Nicolas et al. 1997; Ruffel et al. 2002; Schaad and Carrington 1996; Yamanaka et al. 2000, 2002). Therefore, we can speculate that alleles of the $N s v$ gene could code for factors required for MNSV accumulation at the single-cell level. These factors may directly or indirectly interact with the $3^{\prime}$-UTR of MNSV RNA to promote replication or translation of the virus genome. In fact, it has been shown that functions of the 3'-UTRs of RNA viruses include translation and transcription of viral genomes (Dreher 1999) and that cellular host factors interacting with $3^{\prime}$-UTRs of RNA viruses are required for viral genome replication or translation (Lai 1998). MNSV-264, with a very different 3'UTR, may not require either Nsv or nsv; or, alternatively, it may be able to interact with both of them to allow its genome 
replication or translation. However, our data cannot exclude the possibility that the resistance to MNSV expressed in cells of $n s v / n s v$ melon genotypes is the result of a defense response elicited by the $3^{\prime}$-UTR of the MNSV genome. Further studies are currently under way to investigate the plausibility of these different scenarios.

\section{MATERIALS AND METHODS}

\section{Plants, viruses, and virus inoculations.}

The susceptible (Nsv/- genotype) Cucumis melo cultivar used in this study was cv. PMR-45 (Seminis, Almería, Spain) and the resistant Cucumis melo cultivars (nsv/nsv genotype) were cvs. Planters Jumbo, Primal F1 (both from Syngenta Seeds, Almería, Spain), and PI 161345 (maintained at "La Mayora" germ plasm collection, Málaga, Spain). Other cucurbit species used in this study were Cucumis sativus cv. Bellpuig (Cucurbita maxima $\times$ Cucurbita moschata), cv. Brava (Cucurbita maxima $\times$ Cucurbita moschata), cv. RS841, and Cucurbita ficifolia, all provided by Seminis (Almería, Spain) and C lanatus cv. Sugar Baby (Fitó, Barcelona, Spain). MNSV isolates were MNSV-264 (Díaz et al. 2002), MNSV-M $\alpha 5$ (Díaz et al. 2003), and MNSV-Dutch (Riviere and Rochon 1990). Inoculum for MNSV-Dutch was supplied by D. M. Rochon (Pacific Agri-Food Research Centre, Summerland, British Columbia, Canada). MNSV was maintained and propagated in mechanically inoculated Cucumis melo cotyledons (cv. PMR-45). MNSV virions were purified as described (Díez et al. 1998) from melon cotyledons 4 to 5 days after inoculation, when virus-induced lesions were evident but not yet coalescent. For host-range studies, the plants were grown and maintained after inoculation in a growth chamber with a day length of $16 \mathrm{~h}$, day and night temperatures of approximately 22 and $18^{\circ} \mathrm{C}$, respectively, and day and night relative humidity of approximately 70 and $60 \%$, respectively. Mechanical inoculations were performed on expanded cotyledons for the cucurbit species and in young but fully expanded leaves of seedlings for the rest of the species. Inoculum consisted of purified MNSV at $15 \mu \mathrm{g} / \mathrm{ml}$ in $10 \mathrm{mM}$ potassium phosphate buffer ( $\mathrm{pH}$ 7.0).

\section{RNA extractions and Northern blot analyses.}

Viral RNA was extracted from purified particles as described by Díez and associates (1998). Double-stranded RNA (dsRNA) extracts were prepared as in Aguilar and associates (2002). Total RNA was extracted from healthy and MNSVinfected plants and protoplasts using the TRI reagent (SigmaAldrich, St. Louis) following the manufacturer's instructions. For Northern blot analysis, $2 \mu \mathrm{g}$ of total RNAs or total RNAs corresponding to $2 \times 10^{5}$ protoplasts were incubated at $50^{\circ} \mathrm{C}$ for $1 \mathrm{~h}$ in a solution containing $1 \mathrm{M}$ glyoxal and 50\% dimethyl sulfoxide in $0.5 \mathrm{M} \mathrm{N}, \mathrm{N}$-bis(2-hydroxyethyl)-2-aminoethanesulfonic acid (BES), pH 6.7. Denatured samples were electrophoresed in $1 \%$ agarose gel in $0.5 \mathrm{M} \mathrm{BES}$, pH 6.7, running buffer; blotted onto nylon membranes (Roche Diagnostics, Barcelona, Spain), and RNAs were visualized by staining with methylene blue as described in Sambrook and Russel (2001). After UV crosslinking, membranes were hybridized in a solution containing $50 \%$ formamide at $50^{\circ} \mathrm{C}$ for at least $8 \mathrm{~h}$. For hybridizations, a digoxygenin-11-UTP-labeled cRNA probe was used. The probe was synthesized by in vitro transcribing the plasmid pTOPO-M $\alpha 5 \mathrm{~L} 1$ which contains an MNSV-M $\alpha 5$ full-length cDNA insert (Díaz et al. 2003). For transcription, pTOPO-M $\alpha 5 \mathrm{~L} 1$ was linearized with $K p n \mathrm{I}$, and cRNA was synthesized using SP6 RNA polymerase (Amersham Pharmacia Biotech, Little Chalfont, U.K.). After hybridization, membranes were washed for $15 \mathrm{~min}$, once at room temperature in $2 \times \mathrm{SSC}(1 \times \mathrm{SSC}$ is $0.15 \mathrm{M} \mathrm{NaCl}$ plus $0.015 \mathrm{M}$ sodium citrate) and twice at $65^{\circ} \mathrm{C}$ in $0.1 \times \mathrm{SSC}$. Chemiluminescent detection was carried out using the reagents and protocols supplied by a digoxigenin-labeling and detection kit (Roche Diagnostics).

\section{cDNA synthesis, cloning, and sequencing.}

Nucleotide sequences corresponding to the $5^{\prime}$ and $3^{\prime}$ ends of the MNSV-264 RNA were determined by sequencing cDNA clones produced by RT-PCR on 3'-adenylated viral dsRNA and genomic RNA, respectively. For the $5^{\prime}$ end, a poly(A) tail was added to the $3^{\prime}$ ends of the dsRNAs and a cDNA was synthesized following the protocols described by Aguilar and associates (2002). Thus, amplification of the cDNA prepared was carried out by PCR using an oligonucleotide specific for MNSV (5'-cttgctcaaccacttcttcccc-3'; MA77) which was designed based on the MNSV-Dutch sequence (Riviere and Rochon 1990) and an oligo(dT). For the $3^{\prime}$ end, reverse transcription was carried out using as a template viral RNA polyadenylated as described by Díaz and associates (2003) and an oligo(dT). Amplification of the cDNA was performed in a PCR reaction with $5^{\prime}$ agggtgcguatgacgatcactcg-3' (MA76) and an oligo(dT) as priming oligonucleotides. MA76 was designed based on the MNSV-Dutch sequence (Riviere and Rochon 1990). The appropriate DNA bands for both the 5'and 3' ends were excised from the gels, purified, ligated to the plasmid pGEM-T Easy System II (Promega Corp., Madison, WI, U.S.A.), and cloned in Escherichia coli following standard protocols (Sambrook and Russell 2001). Two clones were chosen and fully sequenced for each of the RNA-ends.

Construction of a full-length cDNA was carried out by RTPCR on encapsulated viral RNA. The primer 5'ataggcctgggcggggggctccgatag- $3^{\prime}$ (MA105), which included the restriction site StuI (underlined), was used in a reverse transcription reaction using Expand reverse transcriptase (Roche Diagnostics) according to the manufacturer's instructions. PCR amplification was performed using the oligonucleotides MA98 and 5'-tgtaatacgactcactatagggattactctagccggatccceg-3' (MA104) and the Expand High Fidelity kit (Roche Diagnostics) following the manufacturer's instructions. MA104 included a T7 RNA promoter sequence (underlined). The obtained DNA fragment was purified, ligated to the pCRBluntII-TOPO plasmid (Invitrogen, Carlsbad, CA), and cloned into E. coli. Plasmid DNA was prepared from two selected clones and the complete nucleotide sequence was determined for one of them (pTOPO-264) once the infectivity of its in vitro transcripts were confirmed (discussed below).

\section{Sequence analyses.}

Analyses of nucleotide sequences coding capacity were performed using the FRAMES (GCG Software Package, Madison, WI, U.S.A.) and ORF Finder (NCBI website) programs. Database searches for similarities were performed with the BLAST search tool at the NCBI website. Sequence alignments were obtained using the ClustalX program (Thompson et al. 1997). Percentages of sequence identity were estimated from aligned sequences as the number of identical residues shared by two sequences multiplied by 100 and divided by the length of the shorter sequence excluding the gaps. Similarity diagrams were obtained using the PLOTSIMILARITY program of the GCG software package (Devereux et al. 1984).

\section{Construction of chimeric viruses.}

Clones pTOPO-264 (discussed above) and pTOPO-M $\alpha 5 \mathrm{~L} 2$ (Díaz et al. 2003) were used to generate infectious clones pTOPO-264/3'M $\alpha 5$ and pTOPO-M $\alpha 5 / 3^{\prime} 264$. To obtain pTOPO-264/3'M $\alpha 5$, a DNA fragment was generated by PCR using as template pTOPO-M $\alpha 5$ L2 (Díaz et al. 2003) and 
primers 5'-agttggtaccgtcgtggc-3' (MA150) and 5'-aaactgcagggc gggatgggccgaaaac-3' (MA148), which contain the restriction sites KpnI and PstI (underlined), respectively. This DNA fragment was digested with $K p n \mathrm{I}$ and $P s t \mathrm{I}$, purified from agarose gel, and ligated into the $K p n \mathrm{I}$ and $P s t \mathrm{I}$ sites of the plasmid pCR-Blunt II-TOPO, thus giving rise to pTOPO-3'M $\alpha 5$. Then, plasmid pTOPO-264 was cut with KpnI and the resulting fragment was agarose gel purified and ligated into pTOPO3'M $\alpha 5$ previously linearized with KpnI. To obtain pTOPOM $\alpha 5 / 3^{\prime} 264$, a DNA fragment was obtained by PCR using as template pTOPO-264 and primers 5'-atagagattctcaggaccc-3' (MA114) and 5'-aaactgcagggcggggggctccgatag-3' (MA149), which contain the restriction site PstI (underlined). This DNA fragment was digested with $K p n \mathrm{I}$ and $P s t \mathrm{I}$, purified from agarose gel, and ligated into the KpnI and PstI restriction sites of the pBSK $(+)$ plasmid (Stratagene, La Jolla, CA, U.S.A.), giving rise to the pBSK-3'264 clone. In parallel, a DNA fragment was PCR amplified using plasmid pTOPO-M $\alpha 5 \mathrm{~L} 2$ and primers 5'-gacggtaccaactgagaatgatg-3' (MA151), which contains a KpnI site (underlined), and 5'-atggcgatggttaaacgc-3' (MA32). This second DNA fragment was KpnI digested and ligated into pBSK-3'264 previously linearized with KpnI, giving rise to pBSK-KpnM $\alpha 5 / 3^{\prime} 264$. The fragment SacI and $B g l$ II was excised from this plasmid and ligated into the corresponding restriction sites of pTOPO-M $\alpha 5 \mathrm{~L} 2$. The $K p n \mathrm{I}$ restriction site in primers MA150 and MA151 is not present in the original sequence of the virus. Its inclusion resulted in a silent $\mathrm{T}$ to $\mathrm{C}$ substitution at position 3,916 (GGTACT to GGTACC) which did not affect the phenotype of the resulting viruses (data not shown).

\section{In vitro transcription and inoculation into plants.}

Plasmids pTOPO-264, pTOPO-M $\alpha 5 \mathrm{~L} 2$, pTOPO-264/3'M $\alpha 5$, and pTOPO-M $\alpha 5 / 3^{\prime} 264$, containing the T7 RNA polymerase promoter adjacent to the $5^{\prime}$ end of the viral genome, were linearized with the appropriate restriction enzymes (discussed above), and RNA was transcribed as previously described (Díaz et al. 2003). No cap analogue was included in the in vitro transcription reactions because there is substantial evidence of the cap structure not being required for infectivity of the RNA of members of the family Tombusviridae (Hearne et al. 1990; Huang et al. 2000; Rochon and Tremaine 1989). For inoculations, the synthesized transcripts ( 7 to $8 \mu \mathrm{g}$ per cotyledon) were mixed with inoculation buffer ( $3 \mathrm{mM}$ EDTA, $0.11 \mathrm{M}$ sodium pyrophosphate, $\mathrm{pH} 9.0,3 \%$ bentonite, $90 \mathrm{mM}$ glycine) in a $3: 1$ (transcripts/buffer) proportion (vol/vol) and mechanically inoculated by rubbing carborundum-dusted cotyledons. An equivalent amount of viral RNA was used as a control in the infectivity tests. Five days after inoculation, lesions started appearing in the cotyledons of melon, cucumber, and watermelon plants inoculated with either viral RNA or with the in vitro transcribed RNA. Comparison of CP and viral RNA accumulation in transcript RNA and viral RNA-inoculated plants were done as described previously (Díaz et al. 2003). To confirm that infection during resistance breaking or host range experiments occurred without alteration of the viral sequence, the last 600 genomic nucleotides of viral progenies of in vitro-transcribed RNAs were sequenced. Thus, total RNA was extracted from plants inoculated with in vitro transcripts and RT-PCR was performed on these extracts using the primers 5'-actgggggcaatattggtg- $3^{\prime}$ (MA245) and MA148 and MA149. RT-PCR products were sequenced directly.

\section{Preparation and electroporation of melon protoplasts.}

Protoplasts isolation was essentially carried out as described by Moreno and associates (1984). Briefly, melon seeds were uncoated, sterilized in a 5\% sodium hypochlorite solution, and sown in glass tubes ( 25 by $150 \mathrm{~mm}$ ) containing $15 \mathrm{ml}$ of germination medium (Murashige and Skoog solution, $1 \%$ saccharose, $0.08 \%$ agarose, $\mathrm{pH}$ 5.7) (Murashige and Skoog 1962). Tubes containing the seed were maintained first in darkness at $27^{\circ} \mathrm{C}$ for $48 \mathrm{~h}$ followed by a 5-day incubation in a growth chamber with a day length of $16 \mathrm{~h}$, day and night temperatures of approximately 27 and $23^{\circ} \mathrm{C}$, respectively, and day and night relative humidity of approximately $70 \%$. Expanded cotyledons $(1 \mathrm{~g})$ sliced into $1-\mathrm{mm}$-wide pieces then were incubated in $10 \mathrm{ml}$ of LAV 0.5 medium $(1 \times$ macroelements [Sigma-Aldrich], $0.4 \mathrm{M}$ manitol, 0.1 M glycine, $0.51 \mathrm{mM}$ 2-[Nmorpholin] etano sulfonic acid) containing $1.5 \%$ (wt/vol) R-10 Onozuka cellulase (Yakult Biochemical, Tokyo) at $27^{\circ} \mathrm{C}$ for $12 \mathrm{~h}$. The crude protoplast suspension then was filtered through a nylon mesh (80 $\mu \mathrm{m})$, the volume adjusted to $45 \mathrm{ml}$, and centrifuged for $10 \mathrm{~min}$ at $100 \times g$. The protoplast pellet was resuspended in $18 \mathrm{ml}$ of a solution containing $1 \times$ macroelements (Sigma-Aldrich), $0.6 \mathrm{M}$ saccharose, $0.05 \mathrm{M}$ glycine, and $0.51 \mathrm{mM}$ 2-(Nmorpholin) etano sulfonic acid and distributed in centrifuge glass tubes containing $1 \mathrm{ml}$ of LAV 0.5 medium. After centrifugation for 10 $\min$ at $39 \times g$, the protoplasts ring formed in the interphase was recovered, resuspended in $30 \mathrm{ml}$ of LAV 0.5 medium, and centrifuged for $10 \mathrm{~min}$ at $100 \times \mathrm{g}$. The supernatant was discarded, the sediment resuspended in $15 \mathrm{ml}$ of LAV 0.5 medium, and protoplast concentration was estimated.

Protoplasts were inoculated with transcript RNAs by electroporation. Briefly, $1 \times 10^{6}$ protoplasts were resuspended in $800 \mu \mathrm{l}$ of electroporation buffer (0.5 M manitol, $\mathrm{pH}$ 5.7) and mixed with $15 \mu \mathrm{g}$ of transcript RNA. Electroporation was carried out in a Gene Pulser II and Capacitance Extender (BioRad Laboratories, Hercules, CA, U.S.A.) at $125 \mu \mathrm{F}, 180 \mathrm{~V}$, and $100 \Omega$. After electroporation, protoplasts were transferred into a microfuge tube, incubated on ice for $20 \mathrm{~min}$, and centrifuged at $100 \times g$ and $4^{\circ} \mathrm{C}$. The resulting pellet was resuspended in $1.5 \mathrm{ml}$ of LAV 0.5 medium and deposited in 2.5-cm-diameter petri dishes. Inoculated protoplasts were maintained for a variable period of time in a growth chamber with a day length of $16 \mathrm{~h}$, day and night temperatures of approximately 27 and $23^{\circ} \mathrm{C}$, respectively, and day and night relative humidity of approximately $70 \%$.

\section{ACKNOWLEDGMENTS}

V. Truniger was supported by the Ministerio de Ciencia y Tecnología (Programa Ramón y Cajal). This work was supported by grants SCO0064-C2-2 and AGL2000-1156 from Ministerio de Ciencia y Tecnología, Spain. We thank V. Moreno and B. Pineda for their help in preparing melon protoplasts, D. M. Rochon for providing inoculum of MNSVDutch, Y. Hernando and B. Lovic for the critical review of the manuscript before submission, and M. Victoria Martín for technical assistance.

\section{LITERATURE CITED}

Aguilar, J. M., Hernandez-Gallardo, M. D., Cenis, J. L., Lacasa, A., and Aranda, M. A. 2002. Complete sequence of the Pepino mosaic virus RNA genome. Arch. Virol. 147:2009-2015.

Baker, B., Zambryski, P., Staskawicz, B., and Dinesh-Kumar, S. P. 1997. Signaling in plant-microbe interactions. Science 276:726-733.

Bendahmane, A., Kohm, B. A, Dedi, C., and Baulcombe, D. C. 1995. The coat protein of potato virus $\mathrm{X}$ is a strain-specific elicitor of Rx1-mediated virus resistance in potato. Plant J. 8:933-941.

Berzal-Herranz, A., De la Cruz, A., Tenllado, F., Díaz-Ruiz, J. R., López, L., Sanz, A.I., Vaquero, C., Serra, M. T., and García-Luque, I. 1995. The capsicum 1(3) gene-mediated resistance against the tobamoviruses is elicited by the coat protein. Virology 209:498-505.

Coudriet, D. L., Kishaba, A. N., and Bohn, G. W. 1981. Inheritance of resistance to muskmelon necrotic spot virus in a melon aphid-resistant breeding line of muskmelon. J. Am. Soc. Hortic. Sci. 106:789-791.

Culver, J. N. 1997. Viral avirulence genes. Pages 196-219 in: PlantMolecular Interactions, vol. 2. G. Stacey and N. T. Keen, eds. Chapman and Hall, New York. 
Devereux, J., Haeberli, P., and Smithies, O. 1984. A comprehensive set of sequence analysis programs for the VAX. Nucleic Acids. Res. 12:387.

Díaz, J. A., Bernal, J. J., Moriones, E., and Aranda, M. A. 2003. Nucleotide sequence and infectious transcripts from a full-length cDNA clone of the Carmovirus melon necrotic spot virus. Arch. Virol. 148:599-607.

Díaz, J. A., Nieto, C., Moriones, E., and Aranda, M. A. 2002. Spanish melon necrotic spot virus isolate overcomes the resistance conferred by the recessive $n s v$ gene of melon. Plant Dis. 86:694.

Díez, J., Marcos, J., and Pallás, V. 1998. Carmovirus isolation and RNA extraction. Pages 211-217 in: Methods in Molecular Biology, vol. 81. Plant Virology Protocols-From Virus Isolation to Transgenic Resistance. G. D. Foster and S. C. Taylor, eds. Humana Press, Totowa, NJ, U.S.A.

Dreher, T. W. 1999. Functions of the 3 '-untranslated regions of positive strand RNA viral genomes. Annu. Rev. Phytopathol. 37:151-174.

Duprat, A., Caranta, C., Revers, F., Menand, B., Browning, K. S., and Robaglia, C. 2002. The Arabidopsis eukaryotic initiation factor (iso) $4 \mathrm{E}$ is dispensable for plant growth but required for susceptibility to potyviruses. Plant J. 32:927-934.

Erickson, F. L., Holzberg, S., Calderon-Urrea, A., Handley, V., Axtell, M., Corr, C., and Baker, B. 1999. The helicase domain of the TMV replicase proteins induces the $\mathrm{N}$-mediated defense response in tobacco. Plant J. 18:67-75.

Fraser, R. S. S. 1990. The genetics of resistance to plant-viruses. Annu. Rev. Phytopathol. 28:179-200.

Fraser, R. S. S. 1999. Plant resistance to viruses. Pages. 1300-1307 in: Encyclopedia of Virology. A. Granoff and R. G. Webster, eds. Academic Press, San Diego, CA.

Hamamoto, H., Watanabe, Y., Kamada, H., and Okada, Y. 1997. Amino acid changes in the putative replicase of tomato mosaic tobamovirus that overcome resistance in Tm-1 tomato. J. Gen. Virol. 78:461-464.

Harrison, B. D. 2002. Virus variation in relation to resistance-breaking in plants. Euphytica 124:181-192.

Hearne, P. Q., Knorr, D. A., Hillman, B. I., and Morris, T. J. 1990. The complete genome structure and synthesis of infectious RNA from clones of tomato bushy stunt virus. Virology 177:141-151.

Hibi, T., and Furuki, I. 1985. Melon necrotic spot virus. CMI/AAB Descriptions of Plant Viruses, no. 302. Association of Applied Biologists, Warwick, U.K.

Huang, M., Koh, D. C. Y., Weng, L. J., Chang, M. L., Yap, Y. K., Zhang, L., and Wong, S.-M. 2000. Complete nucleotide sequence and genome organization of hibiscus chlorotic ringspot virus, a new member of the genus Carmovirus: Evidence for the presence and expression of two novel open reading frames. J. Virol. 74:3149-3155.

Johansen, I. E., Lund, O. S., Hjulsager, C. K., and Laursen, J. 2001. Recessive resistance in Pisum sativum and Potyvirus pathotype resolved in a gene-for-cistron correspondence between host and virus. J. Virol. 75:6609-6614.

Keller, K. E., Johansen, I. E., Martin, R. R., and Hampton, R. O. 1998. Potyvirus genome-linked protein $(\mathrm{VPg})$ determines pea seed-borne mosaic virus pathotype-specific virulence in Pisum sativum. Mol. PlantMicrobe Interact. 11:124-130.

Lai, M. M. 1998. Cellular factors in the transcription and replication of viral RNA genomes: a parallel to DNA-dependent RNA transcription. Virology 244:1-12.

Lellis, A. D., Kasschau, K. D., Whitham, S. A., and Carrington, J. C. 2002. Loss-of-susceptibility mutants of Arabidopsis thaliana reveal an essential role for eIF(iso)4E during Potyvirus infection. Curr. Biol. 12:1046-1051.

Leonard, S., Plante, D., Wittmann, S., Daigneault, N., Fortin, M. G., and Laliberte, J. F. 2000. Complex formation between potyvirus VPg and translation eukaryotic initiation factor 4E correlates with virus infectivity. J. Virol. 74:7730-7737.

Matsuo, K., Kameya-Iwaki, M., and Ota, T. 1991. Two new strains of melon necrotic spot virus. Ann. Phytopathol. Soc. Jpn. 57:558-567.

Meshi, T., Motoyoshi, F., Adachi, A., Watanabe, Y., Takamatsu, N., and Okada, Y. 1988. Two concomitant base substitutions in the putative replicase genes of Tobacco mosaic virus confer the ability to overcome the effects of a tomato resistance gene, tm-1. EMBO (Eur. Mol. Biol. Organ.) J. 7:1575-1581.

Meshi, T., Motoyoshi, F., Maeda, T., Yoshiwoka, S., Watanabe, H., and Okada, Y. 1989. Mutations in the Tobacco mosaic virus 30-kDa protein gene overcome tm-2 resistance in tomato. Plant Cell 1:515-522.

Moreno, V., Zubeldia, L., and Roig, L. A. 1984. A method for obtaining callus-cultures from mesophyll protoplasts of melon (Cucumis melo L.). Plant Sci. Lett. 34:195-201.

Murashige, T., and Skoog, F. 1962. A revised medium for rapid growth and bio assays with tobacco tissue cultures. Physiol. Plant. 15:473-497.

Murphy, J. F., Blauth, J. R., Livingstone, K. D., Lackney, V. K., and Jahn, M. K. 1998. Genetic mapping of the pvr1 locus in Capsicum spp, and evidence that distinct potyvirus resistance loci control responses that differ at the whole plant and cellular levels. Mol. Plant-Microbe Interact. 11:943-951.

Nicaise, V., German-Retana, S., Sanjuán, R., Dubrana, M. P., Mazier, M. Maisonneuve, B., Candresse, T., Caranta, C., and LeGall, O. 2003. The eukaryotic translation initiation factor $4 \mathrm{E}$ controls lettuce susceptibility to the potyvirus Lettuce mosaic virus. Plant Physiol. 132:1272-1282.

Nicolas, O., Dunnington, S. W., Gotow, L. F., Pirone, T. P., and Hellmann, G. M. 1997. Variations in the VPg protein allow a potyvirus to overcome va gene resistance in tobacco. Virology 237:452-459.

Ohshima, K., Ando, T., Motomura, N., Matsuo, K., and Sako, N. 2000. Comparative study on genomes of two Japanese melon necrotic spot virus isolates. Acta Virol. 44:309-314.

Padgett, H. S., Watanabe, Y., and Beachy, R. N. 1997. Identification of the TMV replicase sequence that activates the $\mathrm{N}$ gene-mediated hypersensitive response. Mol. Plant-Microbe Interact. 10:709-715.

Qu, F., and Morris, T. 1999. Carmoviruses (Tombusviridae). Pages 243247 in: Encyclopedia of Virology. A. Granoff and R. G. Webster, eds. Academic Press, San Diego, CA, U.S.A.

Riviere, C. J., and Rochon, D. M. 1990. Nucleotide-sequence and genomic organization of melon necrotic spot virus. J. Gen. Virol. 71:1887-1896.

Rochon, D. M., and Tremaine, J. H. 1989. Complete nucleotide sequence of the cucumber necrosis virus genome. Virology 169:251-259.

Ruffel, S., Dussault, M. H., Palloix, A., Moury, B., Bendahmane, A., Robaglia, C., and Caranta, C. 2002. A natural recessive resistance gene against potato virus $\mathrm{Y}$ in pepper corresponds to the eukaryotic initiation factor 4E (eIF4E). Plant J. 32:1067-1075.

Sambrook, J., and Russell, D. W. 2001. Molecular Cloning: A Laboratory Manual, 3rd ed. Cold Spring Harbor Laboratory Press, Cold Spring Harbor, NY, U.S.A.

Schaad, M. C., Anderberg, R. J., and Carrington, J. C. 2000. Strain-specific interaction of the tobacco etch virus Nla protein with the translation initiation factor elF4E in the yeast two-hybrid system. Virology 273:300-306.

Schaad, M. C., and Carrington, J. C. 1996. Suppression of long-distance movement of tobacco etch virus in a non-susceptible host. J. Virol. 70:2556-2561.

Szittya, G., and Burgyan, J. 2001. Cymbidium ringspot tombusvirus coat protein coding sequence acts as an avirulent RNA. J. Virol. 75:24112420

Thompson, J. D., Gibson, T. J., Plewniak, F., Jeanmougin, F., and Higgins, D. G. 1997. The CLUSTAL_X windows interface: flexible strategies for multiple sequence alignment aided by quality analysis tools. Nucleic Acids Res. 25:4876-4882.

Weber, H., and Pfitzner, A. J. P. 1998. Tm-2(2) resistance in tomato requires recognition of the carboxy terminus of the movement protein of tomato mosaic virus. Mol. Plant-Microbe Interact. 11:498-503.

Weber, H., Schultze, S., and Pfitzner, A. J. 1993. Two amino acid substitutions in the tomato mosaic virus 30-kilodalton movement protein confer the ability to overcome the Tm-2(2) resistance gene in the tomato. J. Virol. 67:6432-6438.

Wittmann, S., Chatel, H., Fortin, M. G., and Laliberte, J. F. 1997. Interaction of the viral protein genome linked of turnip mosaic potyvirus with the translational eukaryotic initiation factor (iso) $4 \mathrm{E}$ of Arabidopsis thaliana using the yeast two-hybrid system. Virology 234:84-92.

Yamanaka, T., Imai, T., Satoh, R., Kawashima, A., Takahashi, M., Tomita K., Kubota, K., Meshi, T., Naito, S., and Ishikawa, M. 2002. Complete inhibition of tobamovirus multiplication by simultaneous mutations in two homologous host genes. J. Virol. 76:2491-2497.

Yamanaka, T., Ohta, T., Takahashi, M., Meshi, T., Schmidt, R., Dean, C., Naito, S. and Ishikawa, M. 2000. TOM1, an Arabidopsis gene required for efficient multiplication of a tobamovirus, encodes a putative transmembrane protein. Proc. Natl. Acad. Sci. U.S.A. 97:10107-10112.

\section{AUTHOR-RECOMMENDED INTERNET RESOURCE}

National Center for Biotechnology Information: www.ncbi.nlm.nih.gov/ 